\title{
TROPHIC STATUS AND PHYTOPLANKTON LIMITATION CONDITIONS IN A FEW BULGARIAN AND HUNGARIAN DANUBE RIVER WETLANDS
}

\author{
Roumen KALCHEV *, Árpád BERCZIK **, Michaela BESHKOVA *, Mária DINKA **, \\ Hristina KALCHEVA*, Anita KISS** and Edit ÁGOSTON-SZABÓ**
}

* Institute of Biodiversity and Ecosystem Research of Bulgarian Academy of Science, Tsar Osvoboditel Boulevard 1, Sofia, Bulgaria, BG-1000, roumenkalchev@hotmail.com, beshkova_m@yahoo.com, hristinakalcheva@yahoo.com

** Danube Research Institute of Hungarian Academy of Sciences, Centre for Ecological Research, Karolona Street 29, Budapest, Hungary, H-1113, berczik.arpad@okologia.mta.hu, dinka.maria@outlook.hu, kiss.anita@okologia.mta.hu, agoston-szabo.edit@okologia.mta.hu

DOI: 10.1515/trser-2015-0084

KEYWORDS: Secchi depth, chlorophyll-a, phosphorus, nitrogen macrophytes.

\section{ABSTRACT}

The phytoplankton limitation conditions in a few Bulgarian and Hungarian wetlands and in two more sampling sites, one for each Danube stretch, were investigated by means of trophic state index of Carlson (1977) for phytoplankton chlorophyll-a (CHL), Secchi disk depths (SD), total phosphorus (TP), and total nitrogen (TN) concentrations. Phytoplankton of both river sites was not limited by non-algal turbidity, nor was they phosphorus and nitrogen limited. In summer months the studied wetlands were predominantly nitrogen limited, while in spring and autumn limitation by non-algal turbidity prevailed.

RESUMEN: Estado trófico e condiciones de limitación de fitoplancton en dos humedales del río Danubio búlgaro y húngaro.

Las condiciones de limitación de fitoplancton en dos humedales búlgaros y húngaros y en dos más sitios de muestreo para cada tramo del Río Danubio, fueron estudiados por medio de los índice de estado trófico de Carlson (1977) para la clorofila-a (CHL) del fitoplancton, profundidad del disco de Secchi (SD), y por las concentraciones de total de fósforo (TP) y total de nitrógeno (TN). El fitoplancton en ambos sitios del río no estaba limitado por turbidez no algal pero tampoco por fosforo ni nitrógeno. En los meses de verano, los humedales estudiados fueron predominantemente limitados por nitrógeno, mientras en primavera y otoño prevaleció la limitación por turbidez no-algal.

REZUMAT: Starea trofică şi condiții de limitare a fitoplanctonului din câteva zone umede de pe Dunăre, din Bulgaria și Ungaria.

Condițiile de limitare a fitoplanctonului în câteva zone umede din Bulgaria și Ungaria și alte două situri de prelevare a probelor, unul pentru fiecare zonă a Dunării, au fost investigate folosind indicele de stare trofică Carlson (1977) pentru clorofila-a din fitoplancton (CHL), adâncimea discului Secchi (SD), concentraţia totală de fosfor (TP) și cea totală de azot (TN). Fitoplanctonul din ambele râuri a fost limitat de turbiditatea non-algală, dar nu a fost limitat de concentrațiile de azot și fosfor. În lunile de vară factorul limitativ în zonele umede studiate a fost azotul, în timp ce în primăvară și toamnă factorul limitativ prevalent a fost turbiditatea non-algală. 


\section{INTRODUCTION}

According to Lieth (1975) swamps, moors, and similar extremely shallow aquatic ecosystems (i.e. wetlands) are among the most productive territories on the earth. The Danube River adjacent wetlands belong to this category and their high productivity on one hand means utilization of nutrients, but depending on hydrology the primary production could be transformed into fish yield. Probably as a result of considerable wetland reduction and increasing isolation from the main river the fish productivity is decreasing (Kalchev et al., 2007) and depending on connectivity to the main river and prevailing hydrology conditions wetlands are functioning as sinks for nutrient load brought in the floodplain by the river and as filter between terrestrial and the river areas (Hein et al., 2005; Bondar et al., 2007). The capacity of wetlands to act as filter or sink for nutrients depends on the intensity, i.e. on limitation conditions of process of primary production, accomplished by two producers - phytoplankton and macrophytes. While the methodology for measuring phytoplankton productivity is advanced and simplified long time ago (Vollenweider, 1969; Carlson, 1977, 1991) the unified estimation of productivity of both phytoplankton and macrophytes together is still a difficult task (Canfield, 1984) due to the tedious nature of macrophyte measurements, heterogonous, diverse character of wetland biotopes and strong influence of varying hydrology. Nevertheless, the compiled data of nutrient concentrations, main photosynthetic pigment, and water column transparency for several years by application of wide spread methodology for trophic status estimation (Havens, 1994; Gibson et al., 2000; Jarosiewicz et al., 2011; Tosheva and Traykov, 2012; Pęczuła et al., 2014) give the opportunity to get insight into main trophic characteristics and differences between Hungarian (middle Danube) and Bulgarian (the Lower Danube) wetlands.

\section{MATERIALS AND METHODS}

Sampling sites in the Lower Danube River encompassed three marshes located on Belene Island (Murtvo blato, Peschin, and Dyulova bara, forming the wetland group of lake type), the middle of the river side arm located in front of Belene locality, and three other wetlands (Kalimok Canal, Kalimok Marsh, and Brushlen Canal - the wetland group of canal type) in the Kalimok-Brushlen protected area (Fig. 1).

Water samples were taken in spring, summer, and autumn between autumn 2009 and spring 2012. Total nitrogen (TN), total phosphorus (TP), and turbidity at $550 \mathrm{~nm}$ as absorbance were determined colorimetrically with Nova 60 photometer and ready to use kits from Merck. The chlorophyll-a samples after filtering through $0.7 \mu \mathrm{m}$ glass fibre filter and storage in liquid nitrogen were analysed in the laboratory according to ISO 10260 standard (ISO, 1992). The water column transparency was measured by means of Secchi disk. In some cases such measurements were not possible due to low depth and high transparency and therefore we calculated the missing Secchi disk values by means of the regression equation based on absorbance at $550 \mathrm{~nm}$ and Secchi disk readings from the same wetlands when such measurements were possible $(\lg 10(\mathrm{SD})=-0.536-0.653 * \lg 10$ (Absorbance), $\left.\mathrm{n}=14, \mathrm{R}^{2}=0.772, \mathrm{P}<0.00005\right)$.

The sampling campaign of Hungarian wetlands includes Mohács Danube River, Riha and Mocskos wetland sites (Fig. 2) in years 2012 (six visits), 2013 (four visits), and 2014 (three visits). Standard analytical methods (Golterman et al., 1978) were used for determination of suspended particular matter (SPM), total phosphorus (TP), and chlorophyll-a (Chl). Total nitrogen (TN) was determined by TOC analyser (Elemetar-liquiTOC). 


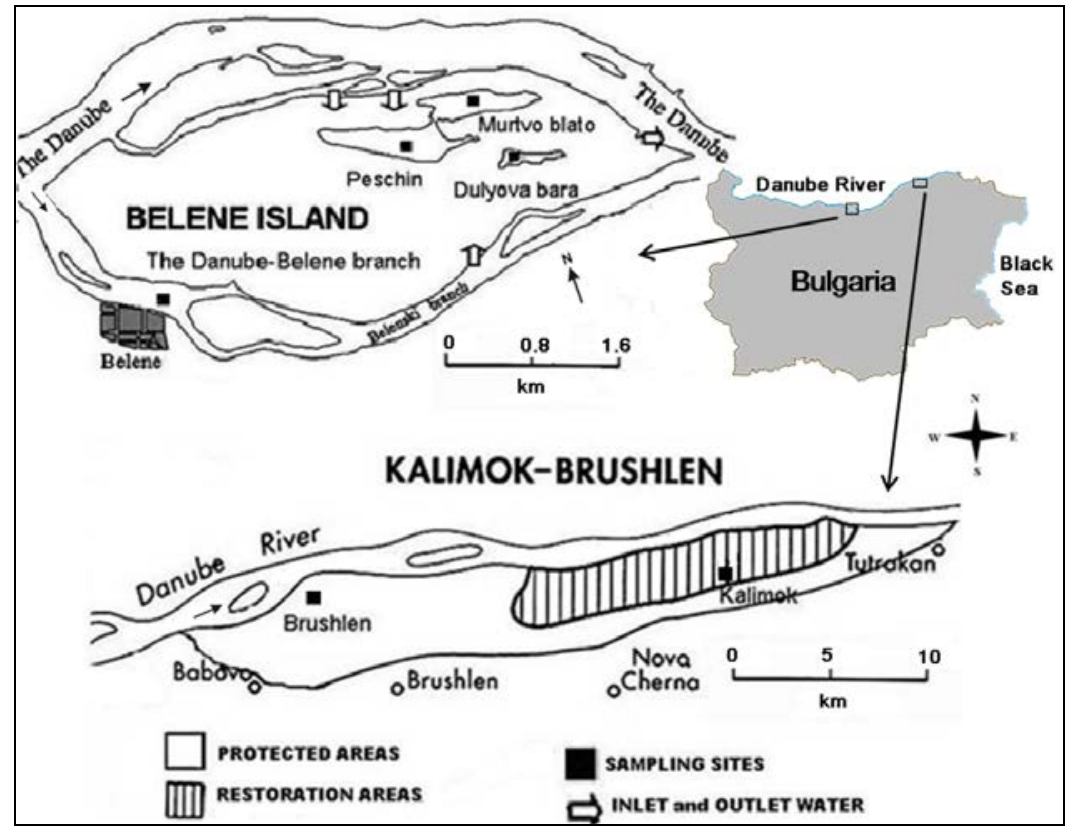

Figure 1: Lower Danube wetland sites on Belene Island (river km 561-576):

Murtvo blato, Peschin and Dyulova bara marshes; Danube River sampling site in front of Belene locality; in Kalimok-Brushlen area river km 440-465:

Kalimok Canal, Kalimok Marsh, Brushlen Canal.

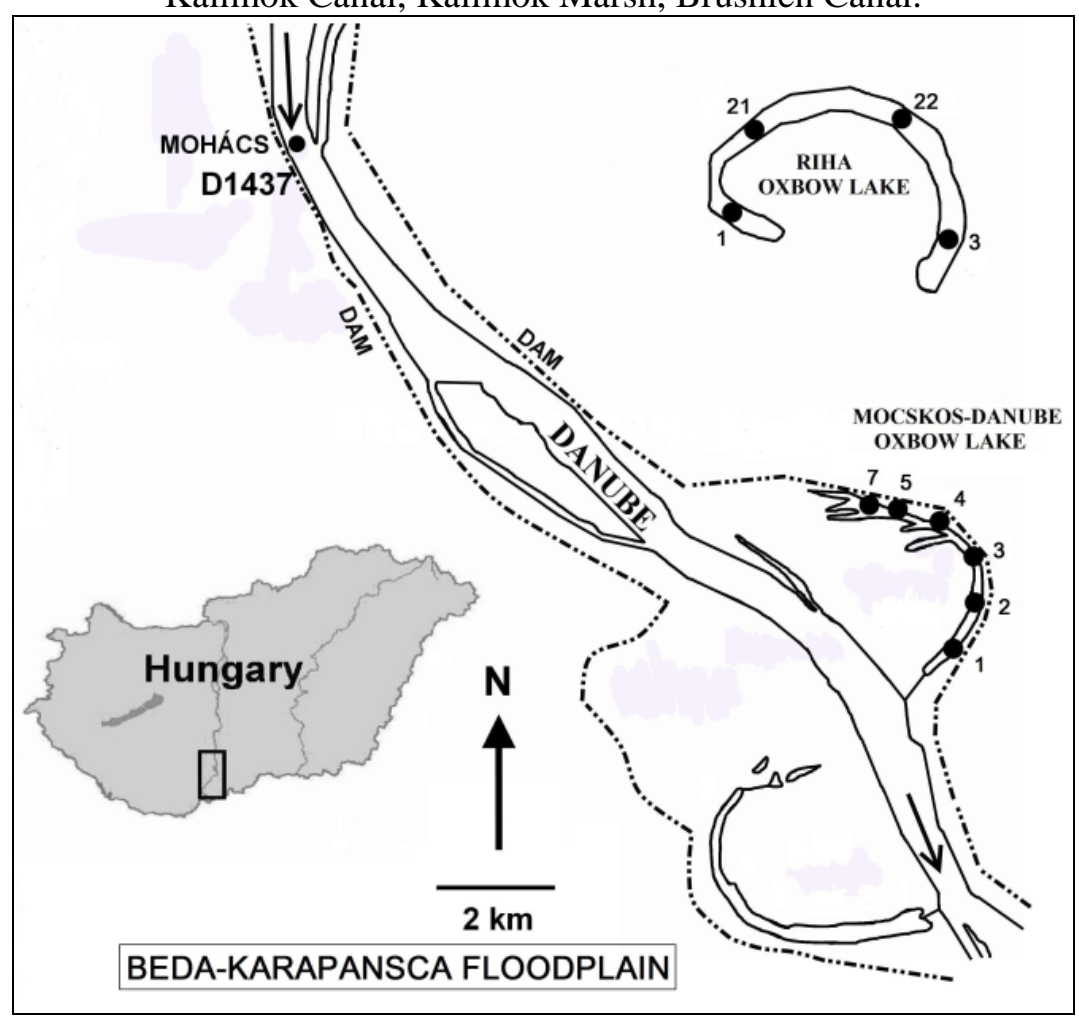

Figure 2: Middle Danube sites: Mohács Danube River, Riha, and Mocskos wetlands. 
Because the SPM data were not appropriate for calculation of trophic state index of Carlson (1977) and no local data were available to convert SPM values into Secchi depth readings for this purpose we used relationships published by Dahlgren et al. (2004). They derived regression equations for California streams and waterways, which were shallow and streaming like most of Hungarian wetlands along the Danube River, which are temporary streaming and temporary stagnant. Due to the shallow nature of such water bodies Dahlgren et al. (2004) measured the water column transparency by means of a tube and calculated the regressing equation between SPM and tube transparency $(\mathrm{TT}) \log _{10}(\mathrm{SPM})=1.17 * \log _{10}$ $(\mathrm{TT})+3.13, \mathrm{R}^{2}=0.51, \mathrm{P}<0.001$. However, the obtained TT values are not identical with Secchi disk readings (SD) and therefore Dahlgren et al. (2004) provided a second equation, converting TT (in cm) into SD (in cm) $-\mathrm{SD}=1.09 * \mathrm{TT}+15.6, \mathrm{R}^{2}=0.71, \mathrm{P}<0.001$. In both studies (Bulgarian and Hungarian) the degree of coverage of water surface by macrophytes (floating and submerged) was also estimated visually as a percentage.

The compiled values of chlorophyll-a (CHL), Secchi disk readings (SD), total phosphorus (TP), and total nitrogen (TN) were converted into trophic state index (TSI) of Carlson using formulas published by Carlson (1977) and Havens (1994). The deviations between four trophic state indices were used to evaluate the kind and degree of nutrient limitation and composition and particle size of seston after Havens (1994). As shown in figure 3 negative differences of TSI of Chl and TSI of nutrients (TP, TN) on the ordinate axis indicates a lack of nutrient limitations and vice versa, while the gradient from negative to positive differences between TSI of Chl and TSI of SD on abscissa axis indicates transition from small to large algae and from non-algal turbidity to zooplankton grazing.

The statistical analysis includes linear regression calculation which was carried out by PAST statistical package (Hammer et al., 2001).

\section{RESULTS AND DISCUSSION}

\section{Limitation conditions}

The deviations between four calculated TSI for Bulgarian wetlands and Danube River in figure 4 (A-C) show that phosphorus never limits the phytoplankton growth. The scatter of Danube River samples in figure 4A demonstrates prevailing limitation by nonalgal turbidity except in one to two summer samplings in which the phytoplankton seems to consist of nitrogen limited large algae. The non-algal turbidity limitation effect in Danube is still a natural situation despite its considerable reduction during the last decades.

In wetlands of lake type on Belene Island situated in the middle of the river the nitrogen limitation is stronger than in the river (Fig. 4B). Four summer samplings have nitrogen limited large algae, while two spring and one summer samplings have small slightly nitrogen limited algae. However, the majority of samplings from these lake type wetlands in autumn and spring are characterized by considerable non-algal turbidity limiting the phytoplankton growth. This turbidity might have two origins: the connection to the river which is more pronounced in spring and autumn and the strong wind influence on these shallow waters (about one $\mathrm{m}$ depth). The zooplankton grazing might also be of importance due to low number or complete fish absence as a result of restricted connection to the river and reduced oxygen concentration during the night, caused by intense decay of plant organic matter. 

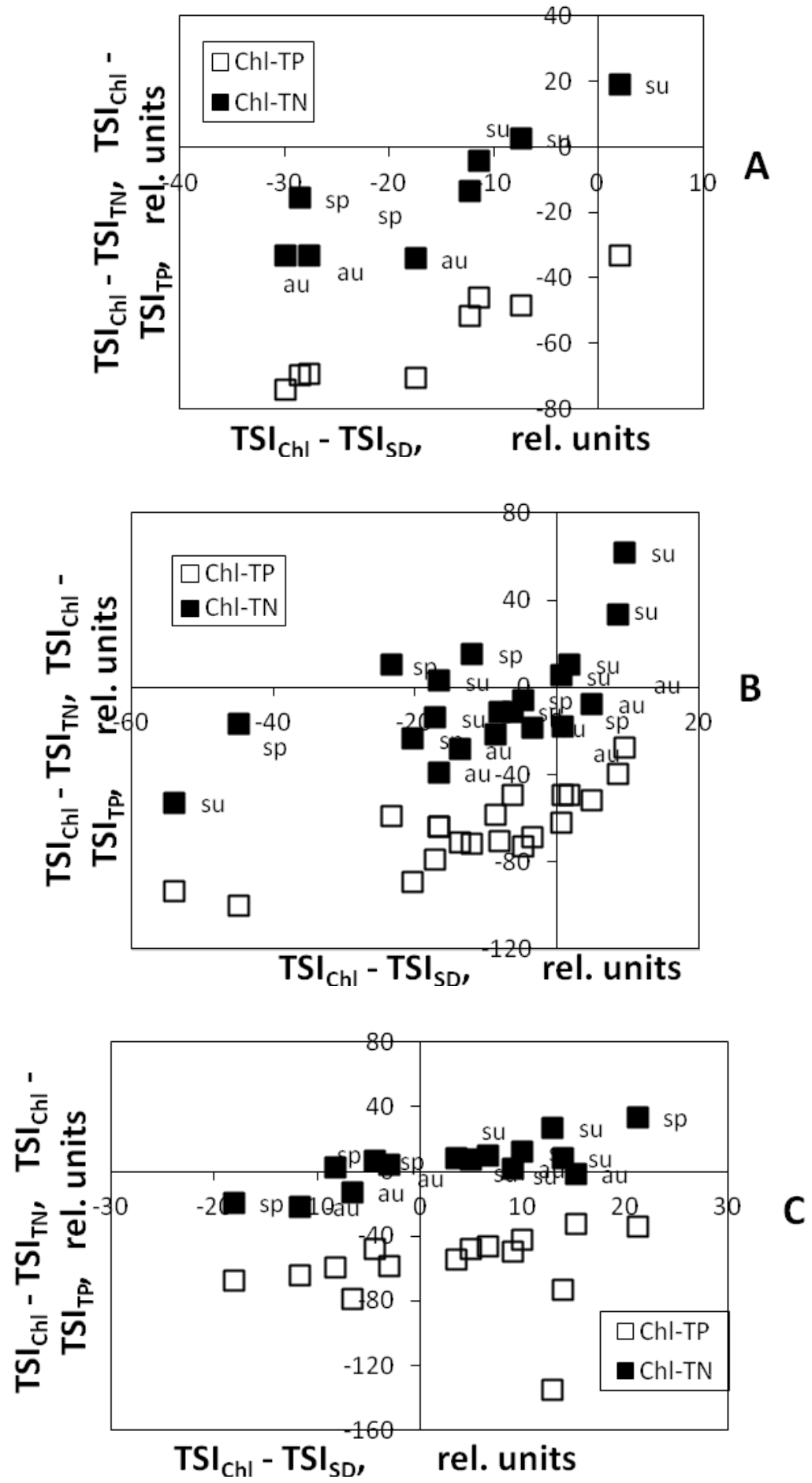

Figure 3: Trophic state index deviations of Danube River (A),

Belene (B), and Kalimok-Brushlen Wetlands (C) sampling sites.

Abbreviations indicate spring (sp), summer (su), and autumn (au) samplings. 
The Bulgarian wetlands of canal type, considerably remote from the river with little or no connection to the river and bordering on cultivated farmland, are distinguished by more clearly expressed nitrogen limited algae (Fig. 4C). Obviously considerable quantities of phosphorus are entering the wetlands by surface run off and ground waters, which leads to nitrogen limitation again more pronounced during the summer months and one spring month of sampling. The non-algal turbidity influence seems to be limited to a few samplings due to greater depth (up to four-five meters at high river levels) and shelter against wind provided by strong plant growth frequently covering both canal banks.

In the middle Danube River similarly to the Lower Danube the majority of samplings are dominated by non-algal turbidity, which is usual for flowing waters and still valid for the Danube River despite the large number of reservoirs build on its tributaries and similar facilities built in the river itself (Fig. 4A). With very few exceptions phytoplankton of almost all samplings is limited neither by phosphorus nor by nitrogen and the non-algal turbidity might be the only factor affecting algae because the zooplankton seems to have no noticeable effect in this river stretch.

Riha Wetland like the Danube River are neither phosphorus nor nitrogen limited (Fig. 4B). However, the difference is that only spring and part of summer samplings are under the influence of non-algal turbidity. The rest of samplings are exposed to zooplankton grazing, which, as shown, was completely absent in this part of the Danube River. Most probably during summer-autumn months the fish press on zooplankton in this isolated from the river wetland is weakened, which could explain the occurrence of zooplankton grazing.

The Mocskos Wetland demonstrates a weak but clear nitrogen limitation of phytoplankton occurring in some of late summer and autumn months (Fig. 4C). The reason for this might be a lower supply of nitrogen because its catchment is exposed to a lesser agricultural influence than the Riha Wetland. In some of the spring and summer months we observed zooplankton grazing, but there are enough summer samplings in which the nonalgal turbidity was the limiting factor. This heterogeneity of limitations might be the result of different distance to and as a consequence of different exposure of Mocskos Wetland sampling sites to varying Danube influence, while Riha being completely isolated from the river did not demonstrate such variability in limitation conditions.

\section{Trophic status estimation}

Considering the obtained TSI values for all four variables (Chl, SD, TP, and TN) we have to bear in mind that $\mathrm{TSI}_{\mathrm{Chl}}$ is closer to a true, generated productivity (trophy), while the other three, especially when their values are higher than that of $\mathrm{TSI}_{\mathrm{Chl}}$, present potential trophy. By means of the classification scale providing approximate trophic ranges published by Gibson et al. (2000) the TSI $\mathrm{Chl}_{\text {l }}$ of Bulgarian Danube and Belene Wetlands seem to be mesotrophic, while Kalimok Wetland and all Hungarian sites are eutrophic (Tab. 1). However, except the Danube River where no macrophytes are available, the TSI of both Bulgarian and Hungarian wetlands underestimate the real value of whole ecosystem trophy because beside the phytoplankton they also have a strong aquatic macrophyte growth, with considerable and difficult to measure share of total ecosystem primary production. 

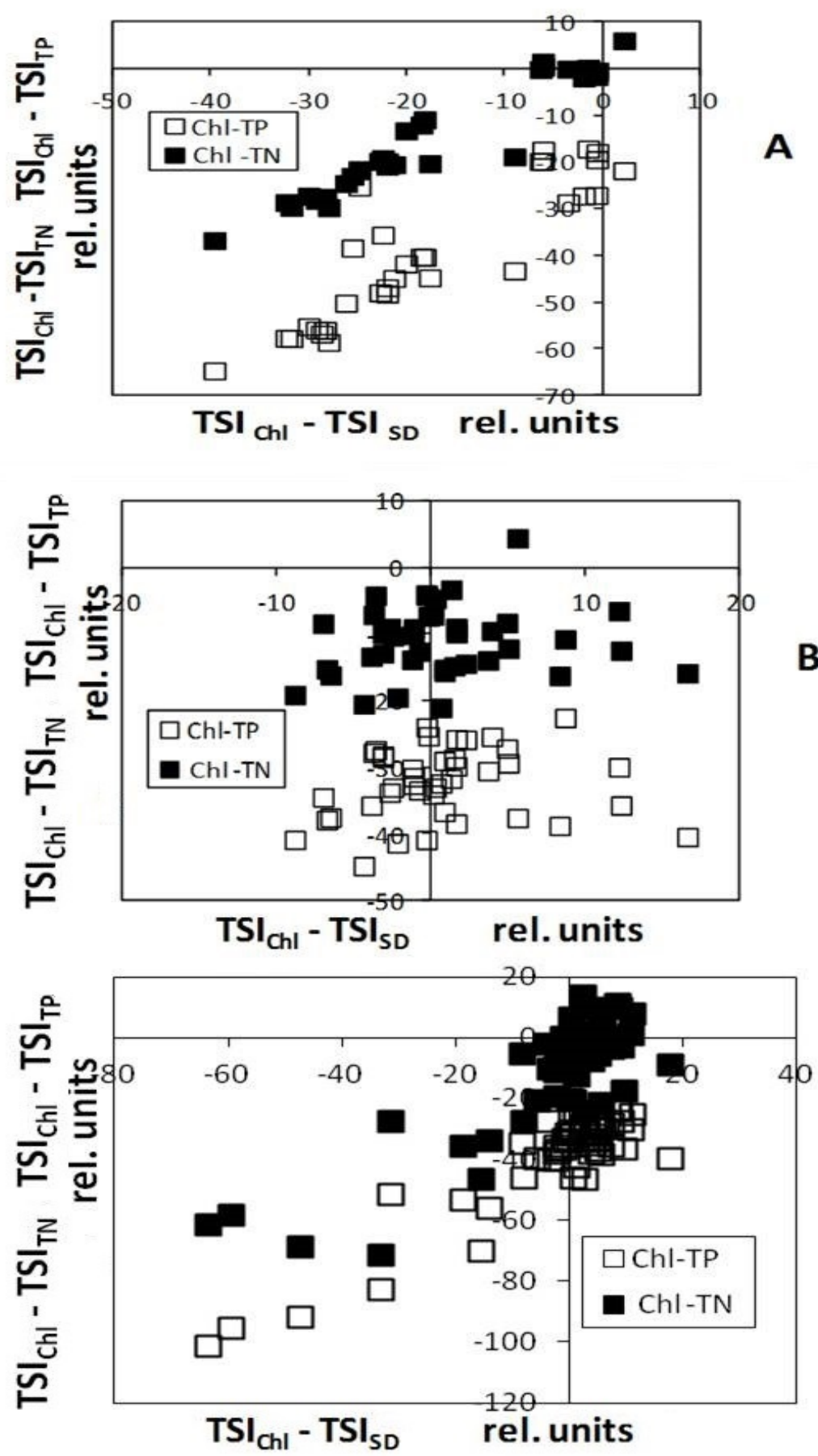

C

Figure 4: Trophic state index deviations of Mohács Danube (A), Riha (B), and Mocskos (C) sampling sites. 
Table 1: Arithmetic means (AM) and standard deviations (STD) of trophic state indices of chlorophyll ( $\left.\mathrm{TSI}_{\mathrm{Chl}}\right)$, total phosphorus $\left(\mathrm{TSI}_{\mathrm{TP}}\right)$ and total nitrogen $\left(\mathrm{TSI}_{\mathrm{TN}}\right)$.

\begin{tabular}{|c|c|c|c|c|c|}
\hline \multicolumn{2}{|c|}{ Sampling Indices } & $\mathrm{TSI}_{\mathrm{Chl}}$ & $\mathrm{TSI}_{\mathrm{SD}}$ & $\mathrm{TSI}_{\mathrm{TP}}$ & $\mathrm{TSI}_{\mathrm{TN}}$ \\
\hline Belene & $\mathrm{AM}$ & 43.7 & 60.3 & 101.6 & 57.7 \\
\hline Danube & STD & 14.3 & 10.0 & 7.6 & 7.0 \\
\hline Belene & $\mathrm{AM}$ & 44.4 & 53.4 & 106.9 & 48.7 \\
\hline Wetlands & STD & 15.0 & 8.6 & 10.8 & 17.7 \\
\hline Kalimok & $\mathrm{AM}$ & 53.6 & 52.4 & 103.7 & 49.4 \\
\hline Wetlands & STD & 14.9 & 6.3 & 15.0 & 10.2 \\
\hline Mohács & $\mathrm{AM}$ & 54.0 & 64.3 & 93.8 & 69.4 \\
\hline Danube & STD & 11.3 & 15.0 & 6.7 & 2.4 \\
\hline Riha & $\mathrm{AM}$ & 57.0 & 56.6 & 93.9 & 65.8 \\
\hline Wetland & STD & 13.5 & 9.4 & 5.8 & 3.3 \\
\hline Mocskos & $\mathrm{AM}$ & 60.9 & 60.1 & 93.4 & 71.9 \\
\hline Wetland & STD & 9.7 & 10.9 & 9.8 & 5.9 \\
\hline
\end{tabular}

This fact has been acknowledged from Porcella et al. (1979), Canfield et al. (1983a, b), Canfield and Jones (1984). Canfield et al. (1983a, b) assume that real trophic state estimated by phosphorus is a sum of quantities in water column and aquatic macrophyte tissue, despite that it is known that macrophytes take up nutrients from both water column and sediment (Porcella et al., 1979; Tosheva and Traykov, 2012). After extensive time and labour intensive investigations Canfield et al. (1983a) showed a considerable increase in lake trophy after adding phosphorus from macrophytes to water column concentrations. Applying the percentage of macrophyte cover, TN, and TP Canfield et al. (1984) obtained multiple regression predicting chlorophyll-a concentration, while Porcella et al. (1979) incorporated the percent macrophyte area covered into a lake evaluation index. 
Based on the well-known negative relationship between macrophyte growth and phytoplankton chlorophyll-a, our experience that macrophyte development varies between years and seasons, we tested the relationship between four derived trophic state indices and percentage area covered by aquatic macrophytes in the hope, that at zero macrophyte cover we will be able to read the real trophic state. We obtained only two statistically significant linear regressions. In Mocskos Wetland, which is nitrogen limited, we obtained $\mathrm{TSI}_{\mathrm{TN}}=71$ $-0.078 * \%$ Area $_{\text {Macrophytes }}, \mathrm{R}^{2}=0.32, \mathrm{P}<0.002$, which means at zero macrophytes the trophic state might be close to hypereutrophic i.e. TSI $=71$. This is bigger than 60.9 for $^{\text {TSI }} \mathrm{Chl}_{\text {l }}$ and close to $\mathrm{AM}$ of $\mathrm{TSI}_{\mathrm{TN}}$ in table 1 (71.9). The second linear regression is $\mathrm{TSI}_{\mathrm{Chl}}=80.6-$ $0.325^{* * \%} \%$ Area $_{\text {Macrophytes }}, \mathrm{R}^{2}=0.24, \mathrm{P}<0.05$ in Bulgarian Kalimok-Brushlen Wetland of canal type. The TSI at zero macrophytes would be 80.6 , which is considerably higher than the table mean value for $\mathrm{TSI}_{\mathrm{Chl}}$ of 53.6. The lack of statistically significant relationships between percentage area covered by macrophytes and other trophic state indices might be due to incomplete data collected about macrophytes. As practiced by Porcella et al. (1979) and Canfield et al. (1983a) we could supplement them with density of macrophyte stocks and utilize recent technical advancements to apply flying drones for better visual estimation of area covered by macrophytes.

\section{CONCLUSIONS}

This paper indicates once more the lack of phosphorus, or very weak and seldom occurring nitrogen limitation in the Middle and Lower Danube River, which indirectly support the previous suppositions in the literature for the limiting role of silica for river phytoplankton (Kalchev et al., 2008). The phosphorus load on wetlands is also considerable and seems even higher than on the river, despite the diminishing effect of abundant macrophyte growth. This leads to nitrogen limitation, which is more expressed in wetlands of the Lower than the Middle Danube. More precise determination of macrophyte share from primary production of wetland ecosystems but also accounting for morphology, hydrology, and possible toxic influences e.g. by cadmium brought into water by phosphorus fertilizers will allow more accurate estimation of wetland trophic status and their capacity to diminish the anthropogenic load on the river.

\section{ACKNOWLEDGMENTS}

This study was funded by the National Scientific Fund of Bulgaria within the project DO 02-352, by the Deutsche Bundesstiftung Umwelt, AZ 24050 project and by the program for collaboration and visit exchange of Hungarian and Bulgarian Academies of Science. We are also very grateful to Buzetzky Győző for his help in the fieldwork, to Gábor Horváth and Bernadett Garad for the chemical analyses. 


\section{REFERENCES}

1. Bondar E., Kurcera-Hirzinger V., Preiner S., Weigelhofer G., Schiemer F. and Hein T., 2007 - The Impact Of An Artificial Water Enhancement Scheme On Phosphorus Dynamics In An Urban Floodplain System In Vienna (Austria), International Review of Hydrobiology, 92, 4-5, 413-427.

2. Canfield D. E. Jr., Langeland K. A., Maceina M. J., Haller W. T., Shireman J. V. and Jones J. R., 1983a - Trophic State Classification of Lakes with Aquatic Macrophytes, Canadian Journal of Fisheries and Aquatic Sciences, 40, 1713-1718.

3. Canfield D. E. Jr. and Jones J. R., 1983b - Assessing the trophic status of lakes with aquatic macrophytes, Lake and Reservoir Management, 1, 1, 446-451, DOI: 10.1080/07438148409354554.

4. Canfield D. E. Jr., Shireman J. V., Colle D. E., Haller W. T., Watkins C. E. and Maceina M. J., 1984 - Predictions of Chlorophyll-a in Florida lakes: Importance of Aquatic Macrophyte, Canadian Journal of Fisheries and Aquatic Sciences, 41, 497-501.

5. Carlson R. E., 1977 - A trophic state index for lakes, Limnology and Oceanography, 22, 361369.

6. Carlson E., 1991 - Expanding the Trophic State Concept to Identify Non-Nutrient Limited Lakes and Reservoirs, Enhancing the states' lake management programs, 1991, 59-71.

7. Dahlgren R., Van Nieuwenhuyse E. and Litton G., 2004 - Transparency tube provides reliable water-quality measurements, California Agriculture, 58, 3, 149-153. http://CaliforniaAgriculture.ucop.edu.

8. Gibson G., Carlson R., Simpson J., Schmeltzer E., Gerritson J., Chapra S., Heiskary S., Jones J. and Kennedy R., 2000 - Nutrient criteria, Technical guidance manual Lakes and Reservoirs https://books.google.bg/books?id=Zh8cbX0W0egC\&pg=SL18-PA2\&lpg=SL18PA2\&dq=Carlson+R.E.+1992+Expanding+the+trophic+state+concept+to+identify+nonnutrient+limited+lakes\&source=bl\&ots=D_AaB3DSnE\&sig=f9xaCPPzWtN10AxZROqZiipJ yRw\&hl=bg\&sa=X\&ved=0ahUKEwjWj5PzfzLAhWKDZoKHT6eB6cQ6AEILTAC\#v=onepage\&q=Carlson\%20R.E.\%201992\%20Exp anding\%20the\%20trophic\%20state\%20concept\%20to\%20identify\%20nonnutrient\%20limited\%20lakes\&f=false

9. Golterman H. L., Clymo R. S. and Ohnstad M. A. M., 1978 - Method for physical and chemical analysis of freshwaters, IBP Handbook no. 8, Blackwell Science Publishing, 213.

10. Hammer D. A., Harper T. and Ryan P. D., 2001 - Palaeontologia Electronica, 4, 1, 9. http://palaeo-electronica.org/2001_1/past/issue1_01.htm

11. Havens K. E., 1994 - Seasonal and spatial variation in nutrient limitation in a shallow subtropical lake (Lake Okeechobee, Florida) as evidenced by trophic state index deviations, Archiv fur Hydrobiologie, 131, 1, 39-53.

12. Hein T., Reckendorfer W., Thorp J. H. and Schiemer F., 2005 - The role of slackwater areas for biogeochemical processes in rehabilitated river corridors: examples from the Danube, Large Rivers, Archiv für Hydrobiologie, Supplement, 155, 1-4, 425-442.

13. ISO 10260, 1992 - Water quality - Measurement of biochemical parameters - Spectrometric determination of the chlorophyll-a concentration, 1-4.

14. Jarosiewicz A., Ficek D. and Zapadka T., 2011 - Eutrophication parameters and Carlson-type trophic state indices in selected Pomeranian lakes, Limnological Review, 11, 1, 15-23.

15. Vollenweider R. (ed.), 1969 - A manual on methods for measuring primary production in aquatic environments, IBP, Handbook no. 12, Blackwell Scientific Publications Oxford and Edinburgh, 212. 